\title{
MAPPING THE RESONANT FREQUENCIES OF UPPER GEOLOGICAL LAYERS IN THE VICINITY OF ABANDONED MINING PIT AT THE ZLATÉ HORY LOCALITY, NORTHERN MORAVIA
}

\author{
Markéta LEDNICKÁ $^{1)}$ *, Zdeněk KALÁB ${ }^{1)}$ and Erzsébet GYŐRI ${ }^{2)}$ \\ 1) Department of Geomechanics and Mining Research, Institute of Geonics, Academy of Sciences of the Czech Republic, \\ Studentská street 1768, CZ-70800, Ostrava-Poruba, Czech Republic \\ ${ }^{2)}$ Kövesligethy Radó Seismological Observatory, MTA CSFK GGI, Meredek u. 18, 1112 Budapest, Hungary
}

*Corresponding author's e-mail: lednicka@ugn.cas.cz

\begin{tabular}{l} 
ARTICLE INFO \\
\hline Article history: \\
Received 3 February 2015 \\
Accepted 13 April 2015 \\
Available online 29 April 2015 \\
\hline
\end{tabular}

Keywords:

Seismic noise

Spectral ratio

Site effect

Mining pit

Seismic refraction measurement

\begin{abstract}
Determination of resonant frequencies of sedimentary layers using measurement of seismic noise has been a widely used technique in the last years. Together with the data from geophysical measurement, borehole documentation and geotechnical properties of soils, it can help to understand geological formation at investigated localities. Mapping resonant frequencies of upper geological layers in the locality of Zlaté Hory is presented in this paper. This study follows from the results of seismological measurement performed in the locality during a winding tower demolition in the year 2011. Significant harmonic vibrations were recorded in the vicinity of the tower during the demolition and a new question arose: "What is the source of those harmonic vibrations?" Although there are not any typical sedimentary layers in the locality, based on the results of seismic noise measurements, resonant frequencies of upper geological structures were determined and analysed together with the results of geophysical measurements and borehole documentation.
\end{abstract}

\section{INTRODUCTION}

Upper geological structures influence a vibration effect on the surface. Especially in the areas with layers of loose sediments above rocky ground, exists a resonant vibration and amplification of ground shaking, what is called site effect (Pitilakis, 2004; Panzera et al., 2013). The site effect is mainly solved in seismically active areas when evaluating seismic hazard and performing microzonation studies (e.g. Ansal, 2004; Ansal et al., 2010; Bard, 2008). However, the information about resonant frequencies of sedimentary layers and amplification of ground shaking is also solved in the surroundings of other seismic loading sources in built-up areas (Olszewska and Lasocki, 2004; Kaláb and Lyubushin, 2008; Driad-Lebeau et al., 2009; Motazedian et al., 2012). Resonant frequency of sedimentary layers depends on parameters of sediments, mainly shear-wave velocities and thickness of sedimentary layers. The amplitude of fundamental resonant peak depends mainly on the impedance contrast between surface soil layers and underlying bedrock (Pitilakis, 2004; Srbulov, 2010). Resonance frequency of sedimentary layers can be determined from seismic noise measurements using HVNR (Horizontal to Vertical Noise spectral Ratio) method (Nakamura, 1989). This method has been widely used because there have been substantial reductions in field data acquisition time and costs. This method was also used in this study to determine resonant frequencies of upper geological layers in the locality at Zlaté Hory, Northern Moravia, the Czech Republic.

The studied area is located in the Jeseníky Mountains near the town of Zlate Hory. The polymetallic deposit at Zlaté Hory was the largest ore district in Northern Moravia. The whole area has a rich mining history. The first reference regarding the panning and shallow mining of gold in this locality dates back to $13^{\text {th }}$ century. The underground extraction of gold, $\mathrm{Cu}, \mathrm{Pb}$ and $\mathrm{Ag}$ was developing from $16^{\text {th }}$ century. In the late $19^{\text {th }}$ century, Fe was also extracted. Modern mining history in this nonferrous metal and gold ore site began in 1952 by drilling exploration and subsequently mining operations started in four localities, namely Zlaté Hory - South, Zlaté Hory Hornické skály, Zlaté Hory - East and Zlaté Hory West. By 1993 mining activities ended in all four locallities. In total, more than $7 \mathrm{kt}$ of ore was extracted (Kotris, 2014). Today, the part of abandoned mine workings in the locality of Zlaté Hory - East is used for speleotherapeutical purposes for children. In nonaccessible underground part, a seismic station of virtual network of North Moravia is in operation. The station is operated by the Institute of Geonics AS CR (Holub et al., 2009). It serves for observation of weak natural seismic activity in this area. Mine workings are being prepared for further utilization in this locality. The oldest medieval mine workings have been declared the cultural heritage and a part of these workings is being prepared for opening to the public as a mining museum (Kotris, 2014). 


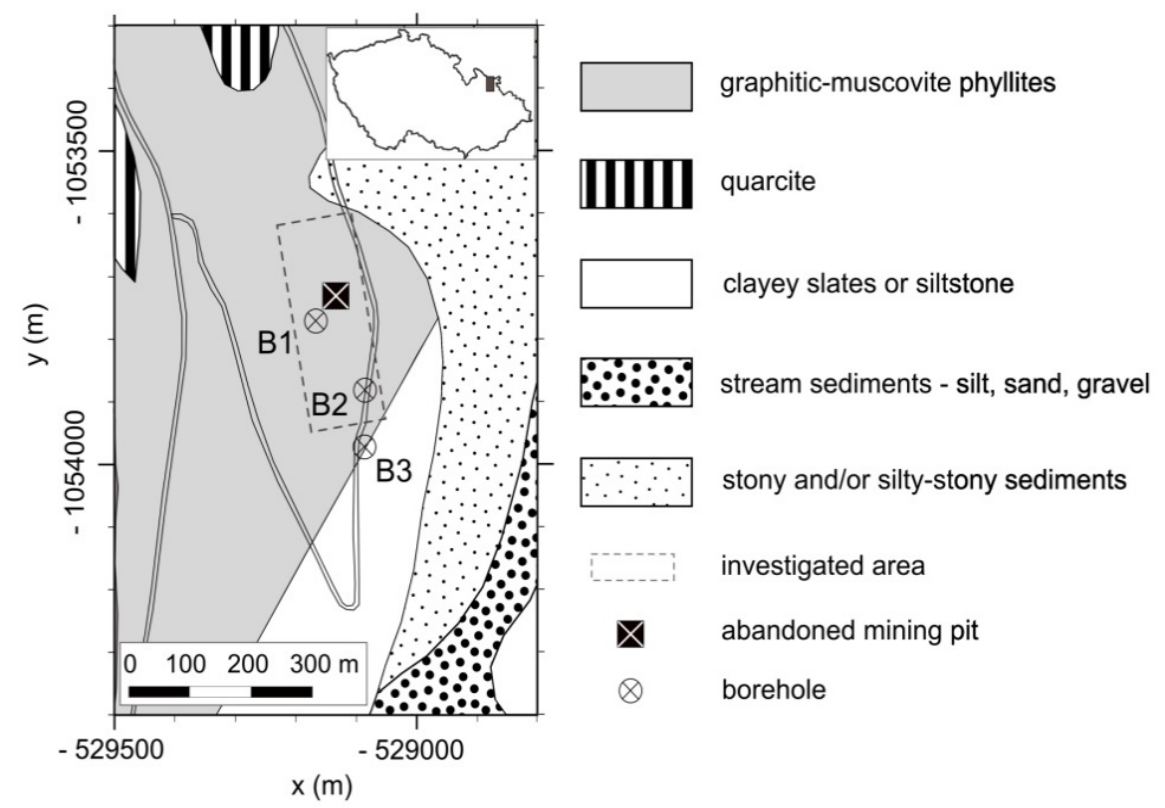

Fig. 1 Generalized sketch of local geology (according to Novotný and Zimák, 2003); Křovák's coordinate system is used.
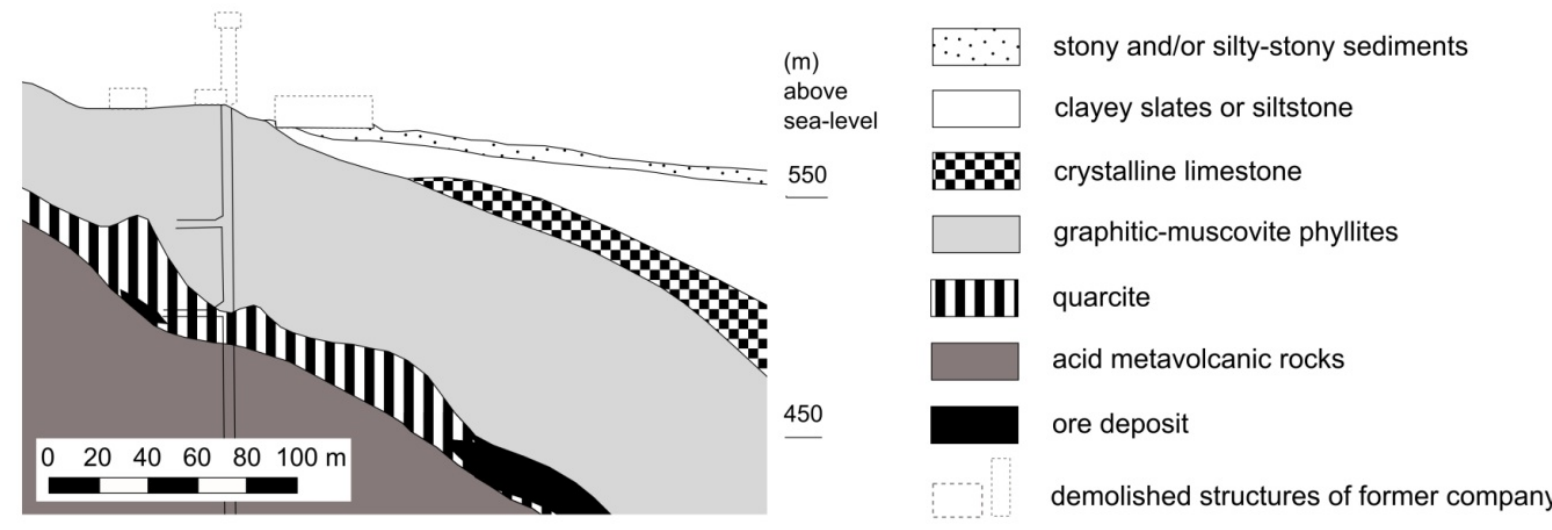

Fig. 2 W-E geological cross section through mining pit (according to Novotný and Zimák, 2003).

In the framework of reclamation works in the locality of Zlaté Hory - East, the demolition of winding tower by using blasting operation was realized in 2011. An experimental seismological measurement was performed near the demolished tower to evaluate vibration effect after the demolition in the near zone (Kaláb and Lednická, 2014). During the tilting of the tower before it fell on the ground, a significant harmonic vibration was recorded on four seismic stations at a distance of $70 \mathrm{~m}$ to $120 \mathrm{~m}$ from the tower. Based on this result the question about the source of these harmonic vibrations arose. We supposed it could be caused by resonant vibration of some structure - natural or artificial. Confirming this idea, we decided to perform mapping of resonant frequencies of upper geological layers in the vicinity of a mining pit using seismic noise measurement. Geophysical measurement was made in the locality and the borehole documentation was also studied for detailed interpretation of obtained frequencies.

\section{LOCAL GEOLOGY}

Local subsurface geology of the studied area and its nearest surroundings is represented by three basic geological units (Fig. 1). Metamorphic rocks (acid metavolcanic rocks, limestone and quartzite) of lower Paleozoic are the oldest unit. Younger geological unit is represented by graphitic-muscovite phyllites, clayey slates and siltstones of the Carboniferrous age. In some parts, quartz and quartzite thin layers are presented in phyllites. Layers of both units are significantly folded and there are inclined to the east in the studied profiles (Fig. 2). In some parts, unconsolidated Quaternary sedimentary deposits (stony and/or loamy-stony sediments, sand, gravel) are possible to find.

Horizontal plane (about $300 \times 100 \mathrm{~m}$ ), where demolished structures of former company were located, was remodelled artificially into a slope (see Fig. 2). This plane was partly made as a cutting. To obtain the information about detailed subsurface 


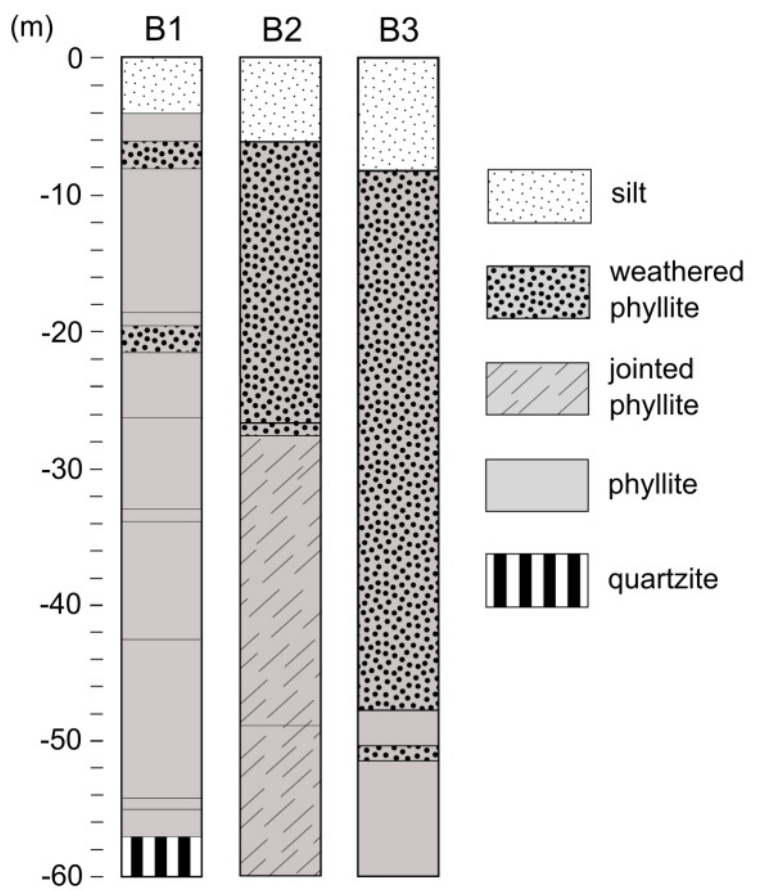

Fig. 3 Borehole profiles with generalised geological pattern.

geological pattern, three boreholes were used from the borehole database of the Czech Geological Survey (Fig. 3). A special attention was paid on unconsolidated and weathered rocks.

\section{HARMONIC VIBRATION RECORDED WHILE DEMOLISHING THE TOWER}

The demolition of the winding tower was realized on April 15, 2011 (Kaláb and Lednická, 2014). The $55 \mathrm{~m}$ high reinforced-concrete construction, weighing 3,000 tons, was demolished by blasting operation using approximately $21 \mathrm{~kg}$ of explosives. Visual perception of the winding tower demolition can be described in three time-divided phases. After the initiation of blasting operation, an intensive pressure and sound wave originated with a significant short-term impulsive character. That was caused by the extraction of the concrete from the destruction profile. In the second phase, a separated structure subsided to its foundations and started to tilt. During the last phase, the tower fell on the ground and totally collapsed. The analysis of recorded wave patterns documented a direct demonstration of blasting operation with recorded air pressure induced wave during the first phase and a complex combination of successively emerging waves, including surface wave during the third phase. The second phase can be characterized as more or less harmonic vibration in the horizontal plane with a gradual increase of the peak amplitudes and then consequent attenuation. The spectrum analysis showed a significant effect in the frequency range 10 $11 \mathrm{~Hz}$. The example of recorded wave patterns on four stations along the profile is in Figure 4.

\section{SEISMIC NOISE MEASUREMENT AND GEOPHYSICAL MEASUREMENT IN THE LOCALITY}

The seismic noise measurement was carried out at 34 points distributed across the area of $300 \times 100 \mathrm{~m}$ (Fig. 5). Two measurements were performed in the year 2013 (16 and 12 points) and one measurement was made at the beginning of the year 2014 (6 points). All of the measurements were taken in good weather conditions; it means there was neither rain nor wind. Each measurement was realized during the daytime. The site is located in a quiet place outside the inhabited area and sources of industrial noise; the nearest road is $220 \mathrm{~m}$ away. The seismic apparatuses GAIA Vistec with three component sensors Vigeo2 (frequency range 2-200 Hz) and Lennartz LE3D (frequency range $1-80 \mathrm{~Hz}$ ) were used for the seismic noise measurement. In the investigated locality, the frequency range of used sensors was assumed to be
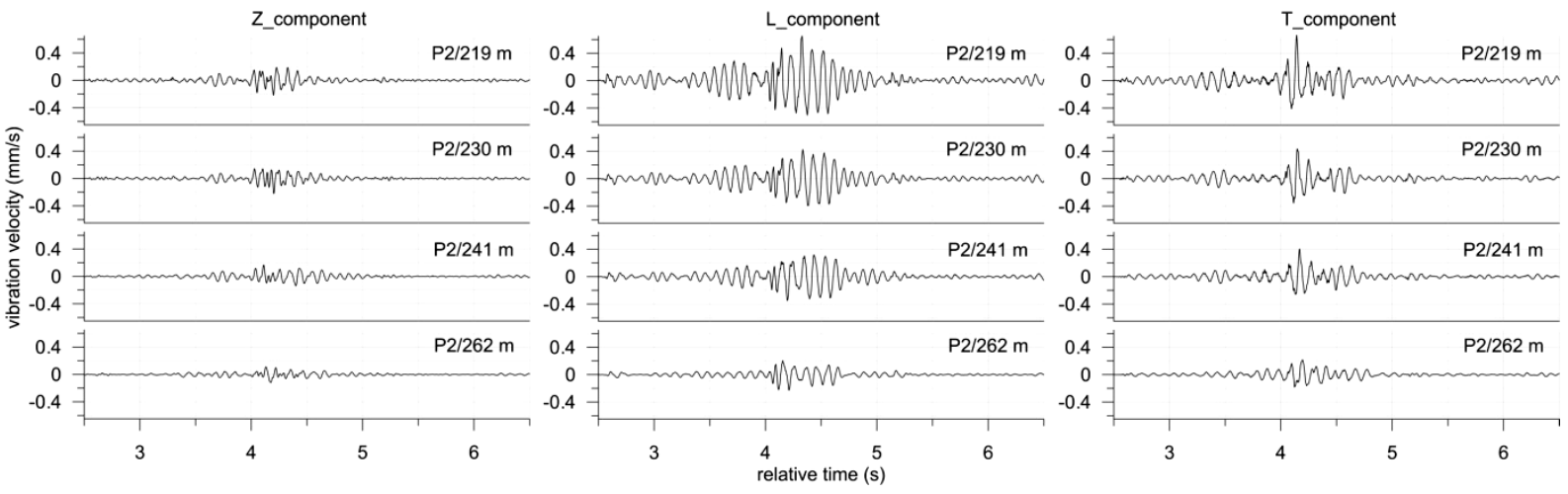

Fig. 4 Wave patterns of second phase of demolition for individual seismic stations: from the top down beginning with the station closest to the foot of the tower to the most distant station (location of station is described as the distance along the profile P2 (Fig. 5)); left to right - vertical, longitudinal (parallel with the direction of profile $\mathrm{P} 2$ ) and transversal components. 


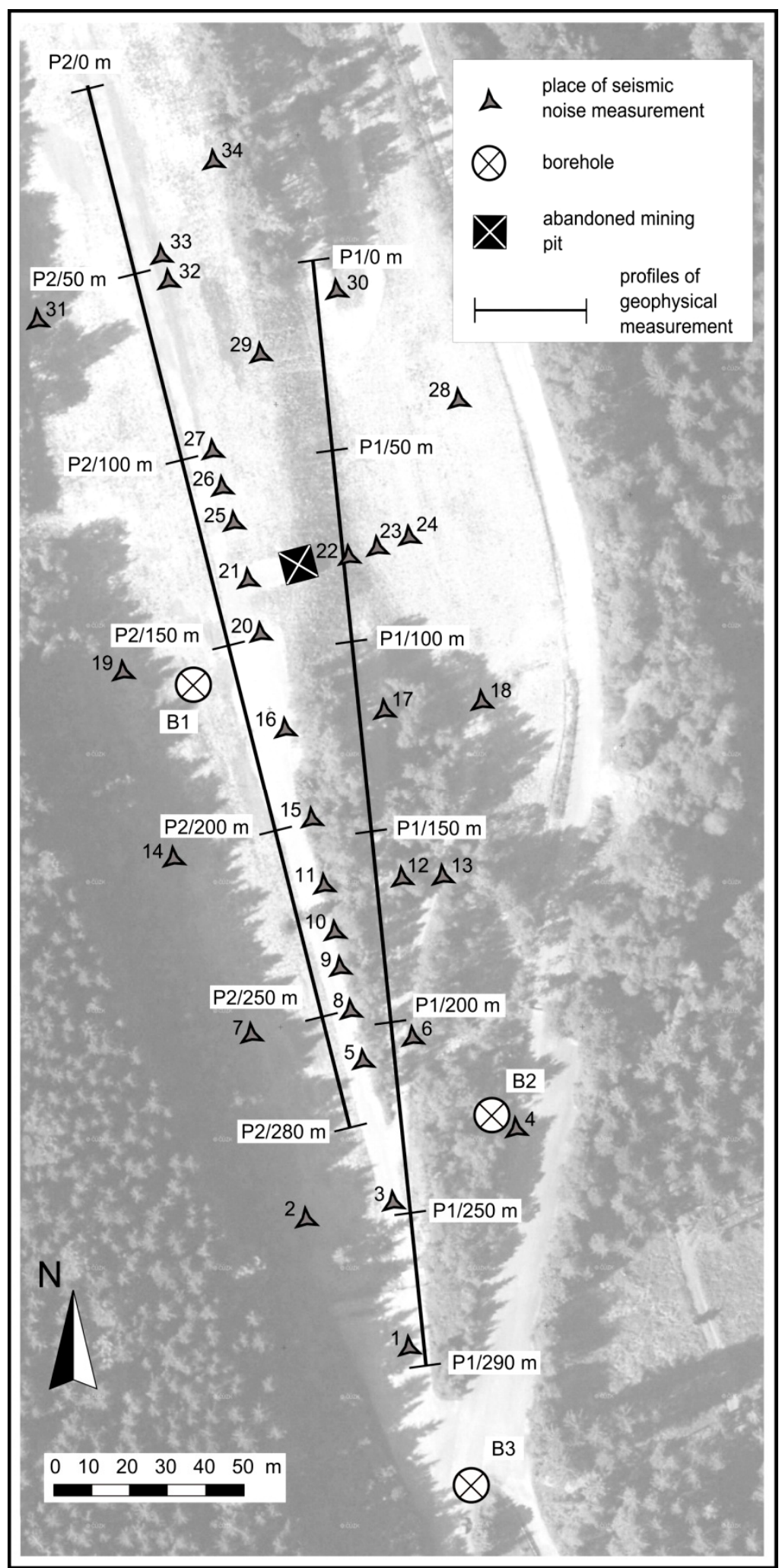

Fig. 5 Location of seismic noise measurements, boreholes and geophysical profiles (underlying map from (Mapy.cz, 2014)). 

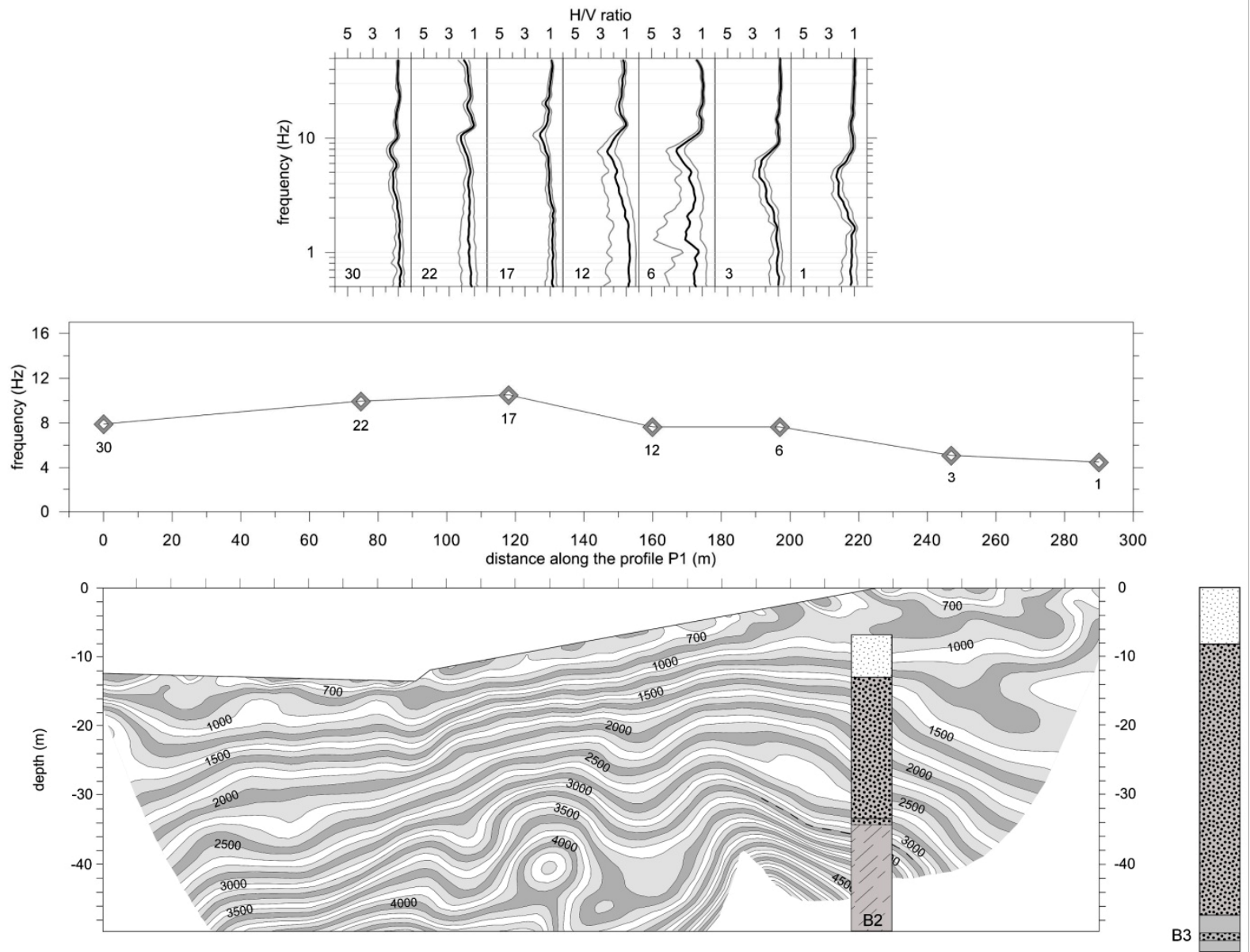

Fig. 6 Profile P1: H/V spectral ratio curves, resonant frequencies, seismic velocity section with borehole profile. Dashed line on the profile indicates possible refracting boundary.

sufficient. We did not expect resonant frequencies lower than $2 \mathrm{~Hz}$ because of shalow depth of sediments and weathered rock above the rocky ground. Expected resonant frequency resulting from the measurement during the tower demolition was approximately $10.5 \mathrm{~Hz}$. At each point was measured a continuous record of seismic noise lasting minimally $30 \mathrm{~min}$. Sampling frequency was set at $250 \mathrm{~Hz}$. The orientation of sensors at all measured points was the same - longitudinal direction was parallel with the direction of profile P2 (see Fig. 5).

Getting more detailed geological pattern in the studied area, seismic refraction measurements were performed on two profiles in autumn 2013 (see Fig. $5)$. Both profiles were realized in the vicinity of the abandoned mining pit and they were 280 and $290 \mathrm{~m}$ long. Seismic apparatuses TERRALOC Mk6 and Geometrix R24 with SM-11 sensors were used. Distances between sensors were $4 \mathrm{~m}$, and the maximum distance source-sensor was $192 \mathrm{~m}$. The individual sources were realized with distances $12 \mathrm{~m}$ along profiles (Filipský, 2013). The result of this measurement is presented as seismic velocity section, it means isoline curves of $\mathrm{Vp}$ seismic velocities (Fig. 6 and Fig. 7).

\section{ANALYSIS OF MEASURED DATA}

Records of seismic noise were analysed by the HVNR method (Nakamura, 1989). This method uses the noise as a seismic input and computes the $\mathrm{H} / \mathrm{V}$ spectral ratio between the horizontal and vertical components of the motion. The data were analysed using Geopsy software (Wathelet et al., 2011). In each record, minimally 20 windows with the length of $20 \mathrm{~s}$ were selected and elaborated. Fourier spectra were computed for each window of each component (vertical component, longitudinal and transversal horizontal components). Before computing the $\mathrm{H} / \mathrm{V}$ spectral ratio, Fourier spectra amplitude of the three components were smoothed with the Konno-Ohmachi smoothing function with smoothing constant equal to 40. Consequently, a squared average was computed for horizontal longitudinal and transversal components. The resulting $\mathrm{H} / \mathrm{V}$ spectral ratio curves show averaged curve and its standard deviation computed for all selected windows. Seismic velocity sections and boreholes were plotted together with selected $\mathrm{H} / \mathrm{V}$ spectral ratio curves for detailed analysis (Fig. 6 and Fig. 7). From each $\mathrm{H} / \mathrm{V}$ spectral ratio curve the resonant frequency was determined and used 

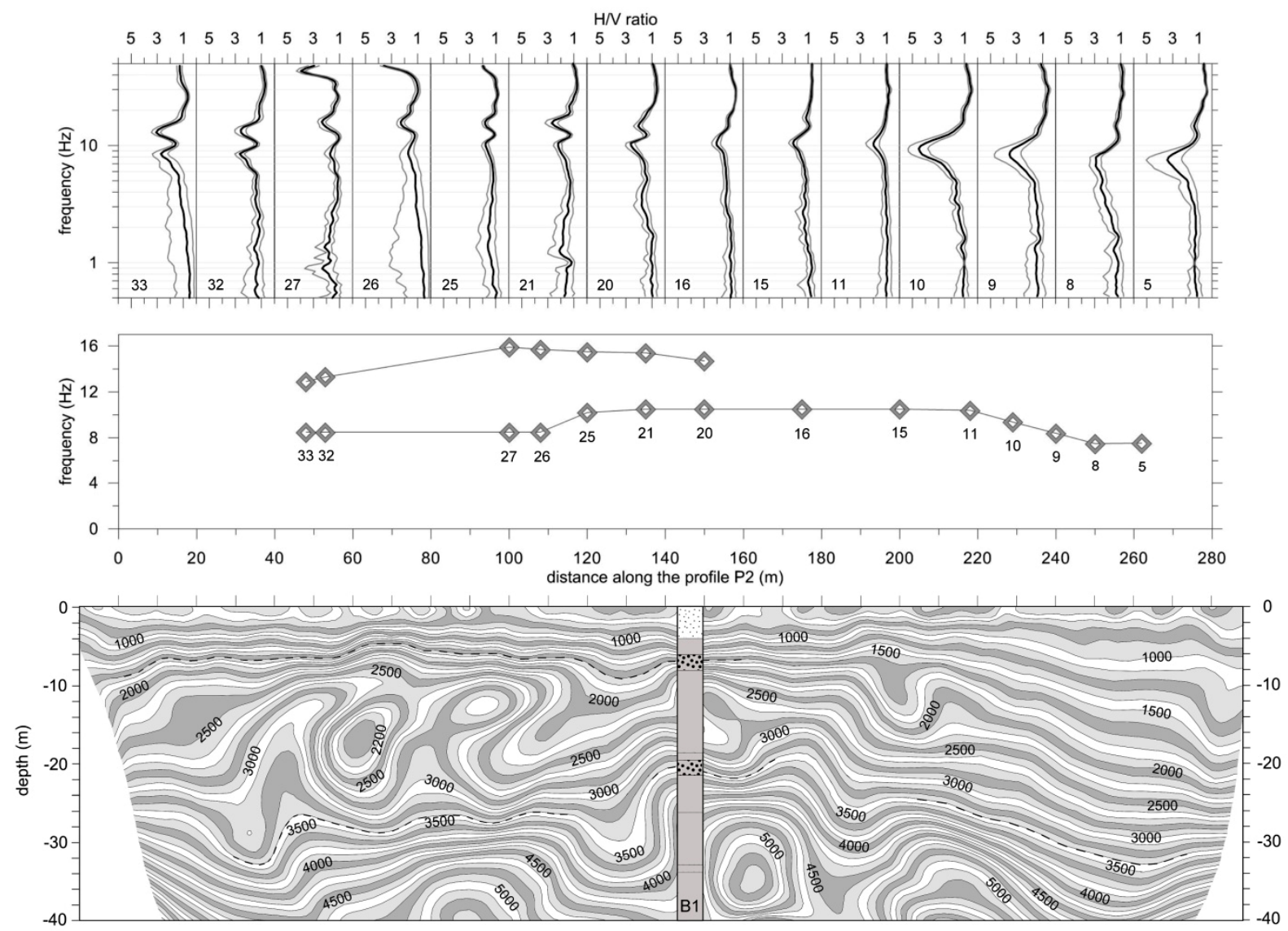

Fig. 7 Profile P2: H/V spectral ratio curves, resonant frequencies, seismic velocity section with borehole profile. Dashed lines on the profile indicate possible refracting boundaries.

for further analysis. The map of resonant frequencies in the investigated area can be seen in Figure 8.

Not only resonant frequency, but also polarization of $\mathrm{H} / \mathrm{V}$ spectral ratio was analysed at selected points along the profile P2 (points no. 1, 8, 16, 21 and 32). This analysis was performed to investigate possible directivity effect related to the abandoned mining pit, local geology or topography. To elaborate directivity, software winMASW was used (Dal Moro, 2010).

\section{RESULTS AND DISCUSSION}

Although the locality under investigation is not typical example of geological structure with sedimentary layers above the rocky ground, results of seismic noise measurements document the existence of resonant frequency of upper geological layers in the locality. Three points located in the western part of an investigated area (points No. 14, 19 and 31) have values of the $\mathrm{H} / \mathrm{V}$ spectral ratio equal to 1.0 because they are located in cutting. There is rocky ground without upper layers of weathered rock and/or sediments. Resonant frequencies were detected in the wide range from $4 \mathrm{~Hz}$ up to $16 \mathrm{~Hz}$ at all other points. In addition, in the northern part of the $\mathrm{P} 2$ profile (distance range from $0 \mathrm{~m}$ to $150 \mathrm{~m}$ ), two close peaks were detected on the $\mathrm{H} / \mathrm{V}$ spectral ratio curves. The amplification is low, usually up to 3.0 only, so the impedance contrast between sediments and bedrock or weathered rock and bedrock is not so strong.

The comparison of results for the $\mathrm{P} 2$ profile is presented in Fig. 7. Seismic velocity section is plotted together with $\mathrm{H} / \mathrm{V}$ spectral ratio curves at 14 points measured along the $\mathrm{P} 2$ profile. At a distance of $150 \mathrm{~m}$, the borehole B1 is located approximately $15 \mathrm{~m}$ west of the profile. It is possible to compare the information about the geological description of core with the seismic velocity section (changes of $\mathrm{Vp}$ velocities). At that point, $\mathrm{H} / \mathrm{V}$ spectral ratio curve exhibits two peaks on the frequencies $10.5 \mathrm{~Hz}$ and 14.7 Hz. According to the borehole description, there are layers of phyllite with different thickness and different amount of quartz beginning at $4 \mathrm{~m}$ below the surface down to the depth of $57 \mathrm{~m}$. There are two thin layers of weathered phyllite rock at depths of $7 \mathrm{~m}$ and $20 \mathrm{~m}$ below the surface. It may be the reason why there exist two impedance contrasts and consequent two peaks on $\mathrm{H} / \mathrm{V}$ spectral ratio curves. Between two layers of weathered rock there is an $11 \mathrm{~m}$ thick layer of phyllite with quartz. When we look at the seismic velocity section at a distance of $150 \mathrm{~m}$, it is possible to find two seismic boundaries of Vp velocities at depths comparable to a location of weathered layers of phyllite and almost constant velocity in the layer of 


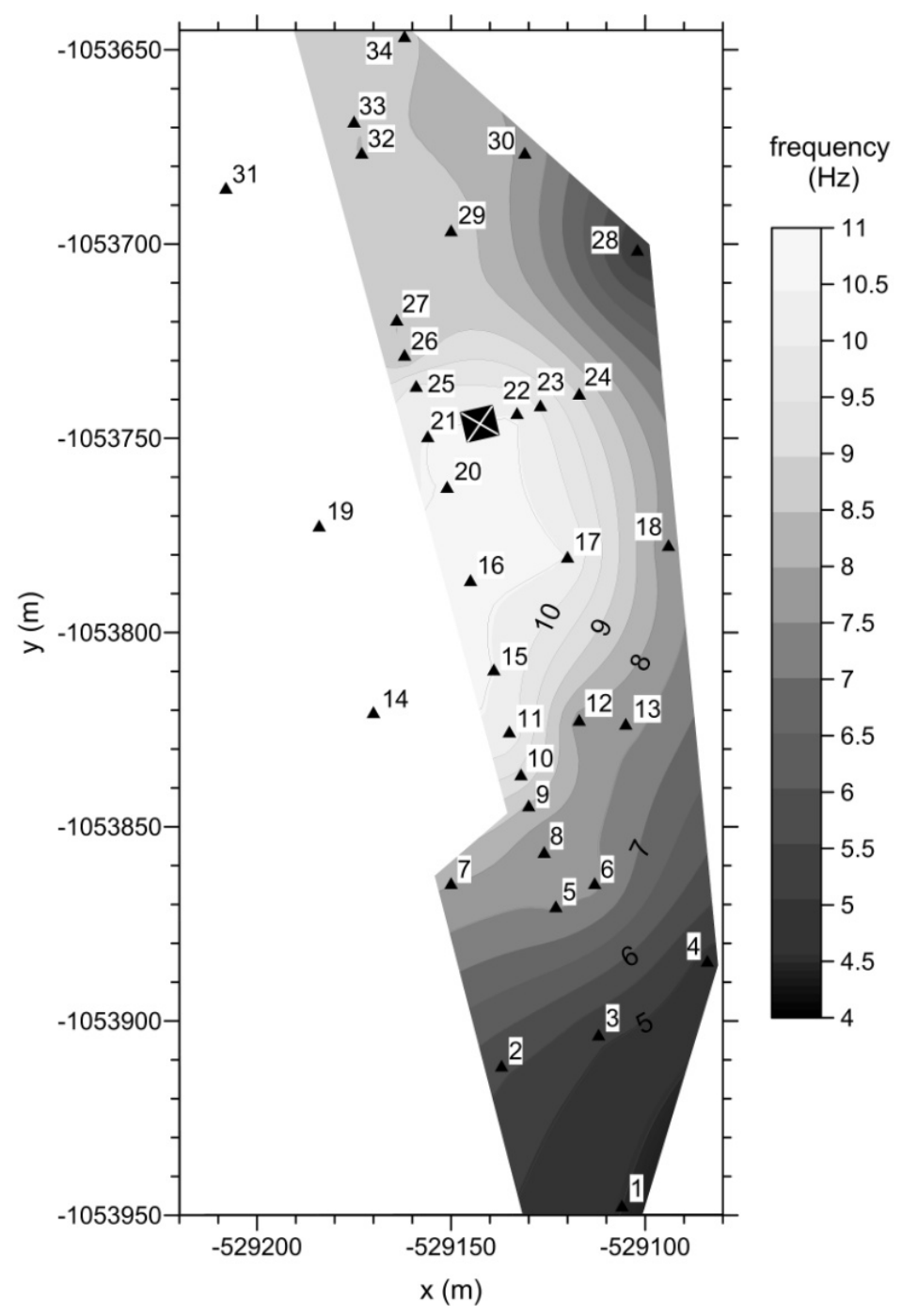

Fig. 8 Map of resonant frequencies (triangles: measured points); Křovák's coordinate system is used.

phyllite between these two boundaries (a depth from $11 \mathrm{~m}$ to $19 \mathrm{~m})$.

Generally, it is possible to divide the profile P2 into two parts. From the beginning of the profile up to the distance of $160 \mathrm{~m}$, there are two evident seismic boundaries, the first one at a shalow depth down to $10 \mathrm{~m}$ and the second one at a depth from $25 \mathrm{~m}$ to $30 \mathrm{~m}$. The right part of the profile, beginning at a distance of $210 \mathrm{~m}$, is quite different. An increase of $\mathrm{Vp}$ velocity is practically constant with the depth. Refracting boundary is detected at a depth from $25 \mathrm{~m}$ to $35 \mathrm{~m}$. The H/V spectral ratio curves correspond to these two parts of the profile P2 (Fig. 7). Two peaks on the curves are detected on the left part of the profile to a distance of $150 \mathrm{~m}$ and correspond to two seismic boundaries. On the right part of the profile, the $\mathrm{H} / \mathrm{V}$ spectral ratio curves exhibit only one peak and the frequency is lower with an increasing profile distance. It indicates an increasing thickness of sediments or weathered rock above bedrock. It is possible to see this trend also at the end of the profile
P1 (Fig. 6). This trend corresponds to the geological pattern. Two boreholes are presented to explain a geological situation near the P1 profile. The borehole $\mathrm{B} 2$ is situated to the east of the profile $\mathrm{P} 1$ in the lower part on the slope near the profile distance of $230 \mathrm{~m}$. The borehole B3 is situated southwards from the end of the profile $\mathrm{P} 1$ at a distance of $30 \mathrm{~m}$. The borehole B2 represents a $26 \mathrm{~m}$ thick layer of silt and weathered phyllite and the borehole B3 represents $47 \mathrm{~m}$ thick layer of silt and weathered phyllite. According to the seismic refraction profile $\mathrm{P} 1$, the most noticeable change of $\mathrm{Vp}$ velocity is at a distance of $200 \mathrm{~m}$ and a depth of $30-35 \mathrm{~m}$. Compared to the borehole B2, this seismic boundary corresponds probably to the boundary between upper layer of weathered phyllite and lower layer of jointed phyllite. At the first part of the P1 profile, the seismic boundaries are not so obvious and the peaks on $\mathrm{H} / \mathrm{V}$ spectral ratio curves are not so clear either.

Based on these results, the map of resonant frequencies was plotted for the investigated area 


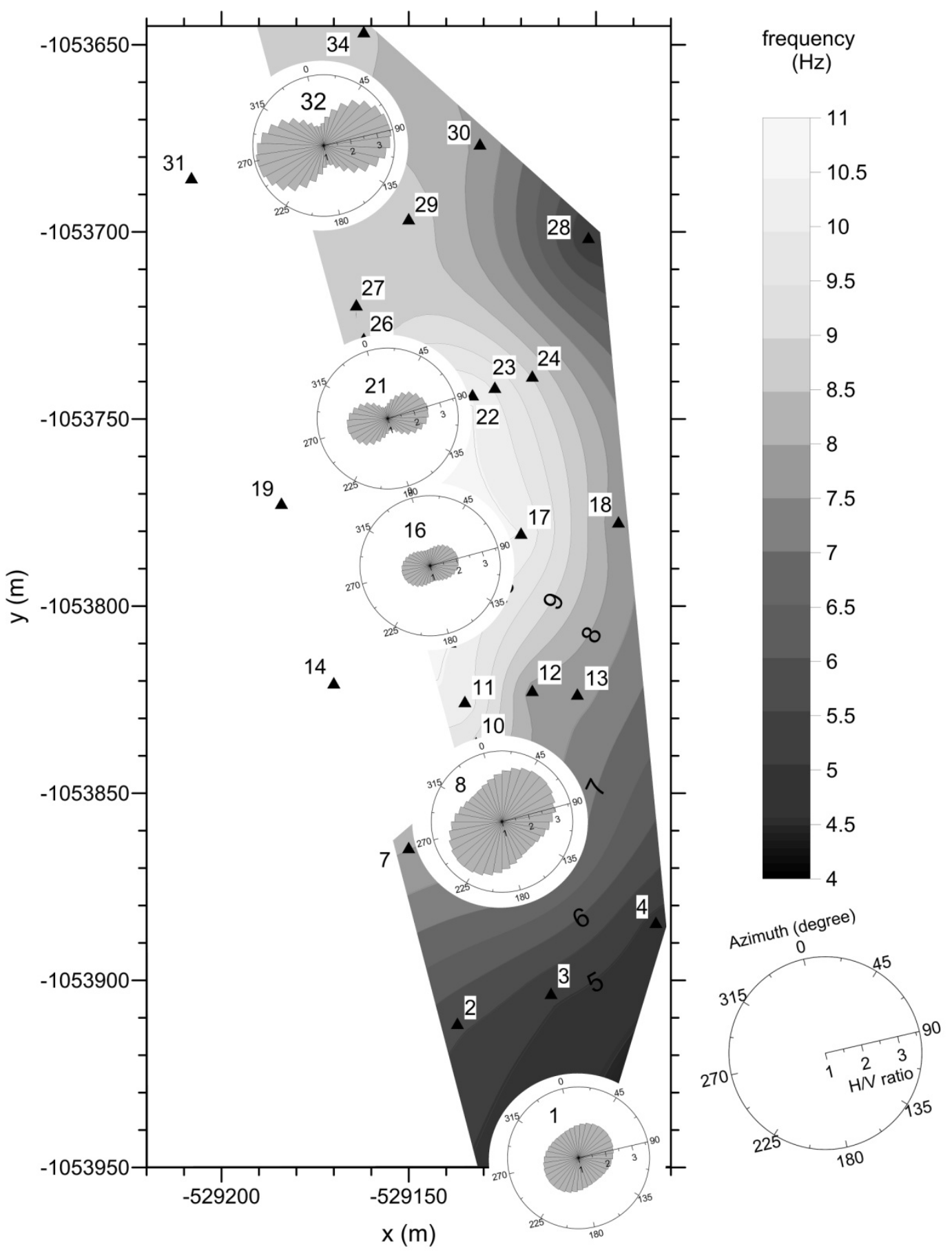

Fig. 10 Directivity elaboration at selected points along the profile P2. Rose diagrams of resonant frequency amplitude are plotted into the map of resonant frequency.

(Fig. 8). At places where two peaks were detected (7 places), the lower value of resonant frequency was used. According to the results of geophysical measurements and borehole documentation, it seems that the lower seismic boundary at places with two frequency peaks is a continuation of seismic boundary at places where only one peak is detected.

Results of directivity analysis are plotted in Figure 9. Azimuthal variations of HVNR are presented on rectangular and on polar diagrams for five elaborated points. Azimuthal angle equal to zero represents longitudinal direction parallel with the direction of the profile $\mathrm{P} 2$. The rectangular plots report frequencies in logarithmic scale while on the polar plots frequencies follow a linear scale. Rose diagrams of resonant frequency amplitude are shown in Figure 10. These data were obtained by filtering recorded seismic noise on the frequency range close to determined resonant frequency for the given point. At places where two peaks on $\mathrm{H} / \mathrm{V}$ spectral ratio curve were detected, rose diagrams were elaborated for the lower value of frequency which corresponds to the 
lower seismic boundary (point no. 21 and 32). It is possible to see in polar diagrams (Fig. 9) that the polarization of a higher resonant frequency amplitude is similar for the lower resonance frequency at the point no. 21. At the point no. 32, it is not possible to see any directivity for higher frequency. The amplitude is practically the same for all directions.

According to the results of directivity elaboration, polarization of resonant frequency corresponding to the lower seismic boundary is maximal in the transversal direction to the profile for all elaborated points along the profile P2. It means that it does not change with the change of local topography and it does not change in the vicinity of the mining pit. Determined direction corresponds probably to the slope of strata of phyllites.

\section{CONCLUSION}

This article presents results of resonant frequency mapping in the vicinity of an abandoned mining pit in the locality of Zlaté Hory. All those investigations were provoked by earlier results of experimental measurements of the vibration effect generated by the demolition of a reinforced-concrete winding tower. During the tilting of a demolished structure, harmonic vibration on frequency of approximately $10.5 \mathrm{~Hz}$ was recorded in the vicinity of mining pit.

Therefore, detailed noise measurements were performed to document the existence of resonant frequency of upper geological layers in the locality. These layers are formed mainly by unconsolidated sediments and weathered rocks. Detailed analyses of determined resonant frequencies, results of geophysical measurement and borehole documentation have confirmed existence of complex geological structure. In one part of the investigated area, two seismic boundaries and consequent two resonant frequencies have also been detected. This detection corresponds with both geological and geophysical description; two layers of sediments and/or weathered rocks are described. Determined resonant frequency is also equal to $10.5 \mathrm{~Hz}$ in the vicinity of the mining pit.

This result has confirmed the hypothesis that harmonic vibration recorded during the tower demolition represents resonant vibration of soil and weathered rock layers in the near zone of the tower where a strong shock was generated. Our study has shown also the phenomenon that response of sloping geological structures to seismic shaking can be characterised by directional variations, with maxima oriented along maximum slope direction.

\section{ACKNOWLEDGEMENT}

This research has been performed with the financial support of the Czech Science Foundation, No. 13-07027P "Investigation of the seismic characteristics of foundation soils using frequency analysis of vibration effects", with the long-term conceptual development support of research organisations RVO: 68145535 and within the frame of cooperation between Hungarian and Czech researchers - bilateral agreement (joint theme „Improvement of the methods of seismic hazard assessment through comparison of methods used by the Institute of Geonics (Ostrava) and Kövesligethy Seismological Observatory (Budapest)“). Presented borehole data are from the database of the Czech Geological Survey.

\section{REFERENCES:}

Ansal, A. (ed.): 2004, Recent Advances in Earthquake Geotechnical Engineering and Microzonation. Series: Geotechnical, Geological and Earthquake Engineering, 1, Kluwer Academic Publishers, Dordrecht, $354 \mathrm{pp}$.

Ansal, A., Kurtuluş, A. and Tőnűk, G.: 2010, Seismic microzonation and earthquake damage scenarios for urban areas. Soil Dynamics and Earthquake Engineering, 30, No. 11, 1319-1328. DOI: $10.1016 / j$.soildyn.2010.06.004

Bard, P.-Y. (ed.): 2008, Bulletin of Earthquake Engineering, Special Issue: The H/V Technique: Results of the SESAME Project, 6, No. 1, Springer, Dordrecht, 147 pp.

Dal Moro, G.: 2010, Insights on surface wave dispersion and HVSR: Joint analysis via Pareto optimality. Jour. Appl. Geophys., 72, No. 2, 129-140. DOI:10.1016/j.jappgeo.2010.08.004

Driad-Lebeau, L., Lokmane, N., Semblat, J. F. and Bonnet, G.: 2009, Local amplification of deep mining induced vibrations. Part 1: Experimental evidence for site effects in a coal basin. Soil Dynamics and Earthquake Engineering, 29, No. 1, 39-50. DOI: $10.1016 /$ j.soildyn.2008.01.014

Filipský, D.: 2013, Reclaimed areal of former mines in Zlaté Hory. Inset s.r.o., Prague, manuscript, 6 pp., (in Czech).

Holub, K., Kaláb, Z., Knejzlík, J. and Rušajová, J.: 2009, Contribution of the Institute of Geonics of the ASCR Ostrava to seismolological monitoring in Silesia and Northern Moravia. Acta Geodyn. Geomater., 6, No. 3(155), 391-398.

Kaláb, Z. and Lednická, M.: 2014, Profile seismological measurement during winding tower demolition. In: 14th International Multidisciplinary Scientific Geoconference and EXPO, SGEM 2014, Conference proceedings, 1, Albena, Bulgaria, 565-572. DOI: $10.5593 /$ sgem2014B11

Kaláb, Z. and Lyubushin, A.A.: 2008, Study of site effect using mining induced seismic events and ambient noise from Karviná region. Acta Geodyn. Geomater., 5, No. 2 (150), 105-113.

Kotris, J.: 2014, Security of "Poštovní štola" gallery in Zlaté Hory region and its accessing to public, In: HPVT Proceedings, Příbram, Czech Rep., CD, 7 pp., (in Czech).

Nakamura, Y.: 1989, A method for dynamic characteristics estimation of subsurface using microtremor on the ground surface. Quart Rep Railway Tech Res Inst, 30, No. 1, 25-33. 
Novotný, P. and Zimák, J.: 2003, Zlaté Hory. History and present of gold deposit with European significance. Memoria Olomouc, 62 pp.,(in Czech). Available from: http://www.hornictvi.info/cteni/zhory/zhory.htm.

Mapy.cz: www.mapy.cz, cit. 5.11.2014.

Motazedian, D., Hunter, J.A., Sivathayalan, S., Pugin, A., Pullan, S., Crow, H. and Khaheshi Banab, K.: 2012, Railway train induced ground vibrations in a low Vs soil layer overlying a high Vs bedrock in Eastern Canada. Soil Dynamics and Earthquake Engineering, 36, 1-11. DOI: 10.1016/j.soildyn.2011.02.008

Olszewska, D. and Lasocki, S.: 2004, Application of the horizontal to vertical ratio technique for estimating the site characteristics of ground motion caused by mining induced seismic events. Acta Geophysica Polonica, 52, No. 3, 301-318.

Panzera, F., Lombardo, G., D'Amico, S. and Galea, P.: 2013, Speedy techniques to evaluate seismic site effects in particular geomorphologic conditions: Faults, cavities, landslides and topographic irregularities. In: D'Amico, S. (Ed.): Engineering Seismology, Geotechnical and Structural Earthquake Engineering, InTech, 101-145. DOI: 10.5772/55439.

Available from:

http://www.intechopen.com/books/howtoreference/en gineering-seismology-geotechnical-and-structuralearthquake-engineering/speedy-techniques-toevaluate-seismic-site-effects-in-particulargeomorphologic-conditions-faults-ca.

Pitilakis, K.: 2004, Site effect. In: Ansal, A. (Ed.): Recent advance in earthquake geotechnical engineering and microzonation, Kluwer Academic Publisher, Dordrecht, 139-197.

Srbulov, M.: 2010, Ground Vibration Engineering. Series: Geotechnical, Geological and Earthquake Engineering, 12, Springer, $233 \mathrm{pp}$.

Wathelet, M. et al.: 2011, Geophysical signal database for noise array processing (GEOPSY), free download available at the web-site:

http://www.geopsy.org/download.php 

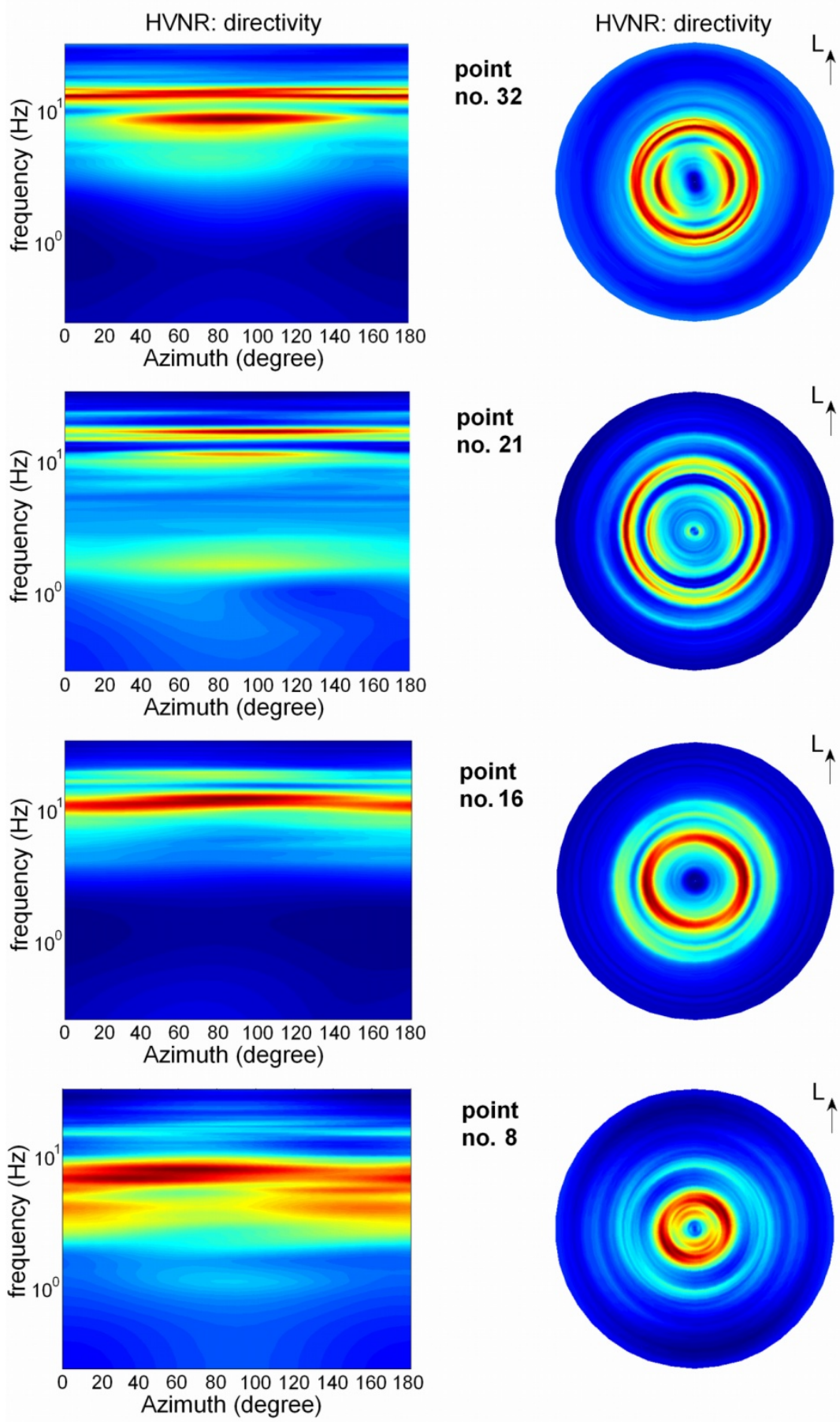

point

no. 8
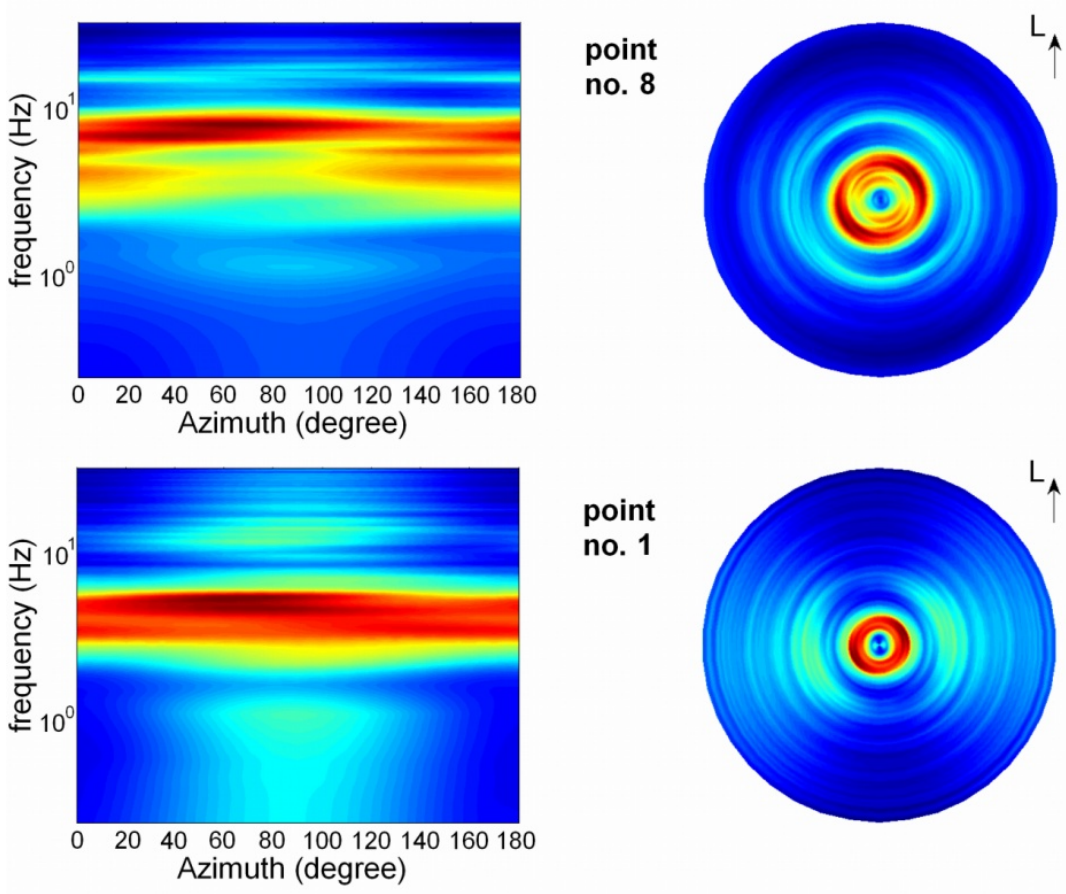

Fig. 9 Directivity elaboration at selected points along the profile P2. Azimuthal variations of HVNR are presented on rectangular and on polar diagrams. 